\title{
Сучасні хірургічні технологіі у лікуванні пацієнтів з поєднаною патологією анального каналу і прямої кишки
}

\author{
М. П. Захараш ${ }^{1}$, В. В. Балицыкий ${ }^{2,3}$, О. Г. Курик ${ }^{4}$
}

${ }^{1}$ Національний медичний університет імені О. О. Богомольця, м. Київ, ${ }^{2}$ Вінницький національний медичний університет імені М. І. Пирогова, ${ }^{3}$ Хмельницька обласна лікарня,

${ }^{4}$ Науково-практичний центр профілактичної та клінічної медицини ДУС, м. Київ

\section{Modern surgical technologies in treatment of patients with combined anorectal pathology}

\author{
M. P. Zakharash ${ }^{1}$, V. V. Balytskyy ${ }^{2,3}$, O. G. Kuryk ${ }^{4}$ \\ ${ }^{1}$ Bogomolets National Medical University, Kyiv, \\ ${ }^{2}$ National Pyrogov Medical University, Vinnytsya, \\ ${ }^{3}$ Khmelnytskyi Regional Hospital, \\ ${ }^{4}$ Scientific-Practical Centre of Prophylactic and Clinical Medicine, Kyiv
}

\section{Реферат}

Мета. Покращення результатів хірургічного лікування пацієнтів з поєднаною патологією анального каналу і прямої кишки шляхом застосування високочастотного електрохірургічного апарата «KLS Martin».

Матеріали і методи. Проаналізовані результати лікування 50 пацієнтів з поєднаною патологією анального каналу і прямої кишки з використанням високочастотного електрохірургічного апарата «KLS Martin».

Результати. Застосування високочастотного електрохірургічного апарата «KLS Martin» зменшувало тривалість операції до $(15 \pm 5)$ хв, об’єм крововтрати до $(20 \pm 10)$ мл, потребу в наркотичних аналгетиках до $(2 \pm 1)$ мл, строки стаціонарного лікування до (4 \pm 1$)$ доба.

Висновки. У разі використання високочастотного електрохірургічного апарата «KLS Martin» скорочується тривалість операції, зменшується об'єм крововтрати під час операції, а також інтенсивність больового синдрому в післяопераційному періоді. Після застосування зазначеної електрохірургічної технології глибина некрозу тканин незначна - $(0,192$ $\pm 0,12)$ мм, чим забезпечується косметичність операції.

Ключові слова: високочастотний електрохірургічний апарат «KLS Martin»; поєднана патологія; анальний канал; пряма кишка Abstract

Objective. Improvement of the surgical treatment results in patients with coexistant pathology of anal channel and rectum, using a high-frequency electro-surgical apparatus «KLS Martin».

Materials and methods. Results of treatment of 50 patients, suffering coexistant pathology of anal channel and rectum, using a high-frequency apparatus «KLS Martin», were analyzed.

Results. Application of a high-frequency electro-surgical apparatus «KLS Martin» have reduced the operation duration to (15 $\pm 5) \mathrm{min}$, the blood loss volume - to $(20 \pm 10) \mathrm{ml}$, the need in narcotic analgetics - to $(2 \pm 1) \mathrm{ml}$, and the terms of a stationary treatment - to $(4 \pm 1)$ days.

Conclusion. While application of a high-frequency electro-surgical apparatus «KLS Martin» the operation duration shortens, intraoperative blood loss diminishes, as well as the pain syndrome intensity in postoperative period. After application of this electro-surgical technology the tissues necrosis depth is nonsignificant $-(0.192 \pm 0.12) \mathrm{mm}$, what guarantees the operation cosmetics

Keywords: high-frequency electro-surgical apparatus «KLS Martin»; combined pathology; anal channel; rectum.

У пацієнтів з поєднаною патологією анального каналу і прямої кишки більшість авторів схиляються до виконання одноетапних оперативних втручань з огляду на такі їх переваги, як усунення одразу двох і більше захворювань аноректальної ділянки, економічний ефект, зумовлений скороченням кількості ліжко-днів і незастосуванням медикаментів, уникнення негативного психологічного ефекту, пов'язаного з потребою виконання другої операції, які мають вплив на результат втручання і покращують якість життя пацієнтів $[1,2]$. Прогресивний розвиток сучасних технологій привів до швидкого впровадження в практику колопроктологів нових методів хірургічного лікуван- ня аноректальної патологіі. Зокрема, для лікування геморою широко використовують електротермічну систему «Liga Sure» для коагуляції і перетину судин у діаметрі до 7 мм, розроблену компанією «alleylab» (США). В основі цієї системи лежить механізм впливу на тканини через розплавлення колагену та еластину з формуванням щільної плівки по типу «завареної зони», яка відмежовує рану від зовнішнього середовища, запобігаючи ії інфікуванню. Крім того, немає необхідності у виділенні та лігуванні судинної ніжки гемороїдального вузла. Тому в літературі даний метод лікування називають «закритою безшовною гемороїдектомією» $[3,4]$. Але він має ряд недоліків: у 
1,6 - 7,1\% пацієнтів виникає післяопераційна кровотеча, у 2,1 - 2,9\% - рубцеві стриктури анального каналу [5, 6].

Принцип дії ультразвукового гармонічного скальпеля «Ultra Cision» компанії Ethicon Endo-Surgery (США) побудований на коливанні робочої насадки, що приводить до руйнування водневих сполук у білкових структурах колагену та їх склеювання, внаслідок чого відбувається обтурація просвіту кровоносних судин до 3 мм у діаметрі. Глибина термічного впливу не перевищує 1,5 мм. Вказані властивості цього скальпеля дають можливість виконувати оперативні втручання без прошивання судин з мінімальним термічним впливом на тканини анального каналу, зменшуючи в такий спосіб тривалість операції та інтенсивність післяопераційного больового синдрому [7]. Однак після застосування цього методу частота виникнення післяопераційної кровотечі становить 2,6 - 4\%, а тривалість епітелізації післяопераційної рани збільшується вдвічі порівняно із застосуванням апарата «Liga Sure» [8, 9].

32011 р. в колопроктології для виконання гемороїдектомії активно використовують апарат «En Seal» виробництва компаніï Ethicon Endo-Surgery (США), який забезпечує біполярну електрокоагуляцію тканин з вимірюванням імпедансу та одночасною дисекцією, що уможливлює виконувати стандартну «відкриту» гемороїдектомію без прошивання судинної ніжки. Застосування даної методики позбавлене ускладнень: виражений больовий синдром не виникає у 2,1\% пацієнтів, стриктура анального каналу - у 2,8\%, кровотеча - у 0,5\% [10].

Таким чином, актуальними залишаються активний пошук, розробка та впровадження нових високоефективних методів хірургічного лікування захворювань анального каналу і прямої кишки, які б приводили до мінімальної частоти ускладнень в післяопераційному періоді, зменшення строків загоєння післяопераційної рани і швидкої медико-соціальної реабілітації пацієнтів.

Мета дослідження: покращення результатів хірургічного лікування пацієнтів з поєднаною патологією анального каналу і прямої кишки шляхом використання високочастотного електрохірургічного апарата «KLS Martin».

\section{Матеріали і методи дослідження}

3 жовтня 2017 по серпень 2018 р. у відділенні проктології Хмельницької обласної лікарні прооперовано 50 пацієнтів (досліджувана група) з поєднаною патологією анального каналу і прямої кишки з використанням високочастотного електрохірургічного апарата «KLS Martin» (виробництво німецької компанії «KLS Martin Group», м. Тутлінген), який має систему прогресивного регулювання потужності за допомогою поворотного важеля від 100 до 400 Вт за частоти 450 кГц, що уможливлюе точне ії дозування як у верхньому, так і в нижньому діапазоні та забезпечує універсальність застосування, і два режими монополярного різання: для м'якого розтину тканин без коагуляції і змішаного різання з крайовим коагуляційним ефектом, а також режим «спрей-коагуляції, які забезпечують швидкий і рівномірний гемостаз з мінімальною карбонізацією, що покращує загоєння ран та запобігає їх глибокому некрозу. Чоловіків було 20 (40\%), жінок - 30 (60\%). Вік пацієнтів коливався від 19 до 65 років.
Контрольну групу склали 50 пацієнтів з поєднаною патологією анального каналу і прямої кишки, прооперованих стандартно з використанням металевого скальпеля.

Всі оперативні втручання виконані під спинномозковою анестезією. Всім пацієнтам перед операцією проводили огляд періанальної і параректальних ділянок, виконували пальцеве дослідження анального каналу і прямої кишки, ректороманоскопію, а також з метою дообстеження і виключення патології ободової кишки 17 (34\%) пацієнтам у віці старше 45 років виконали іригоскопію або фіброколоноскопію.

Після оперативних втручань з використанням високочастотного електрохірургічного апарата «KLS Martin» проводили морфологічне дослідження тканин з метою вивчення глибини їх некрозу, а для порівняння використовували операційний матеріал після застосування хірургічного металевого скальпеля.

Тканини фіксували у 10\% розчині нейтрального формаліну. Далі здійснювали їх обробку в гістопроцесорі карусельного типу STP-120. Для виготовлення парафінових блоків використовували станцію EC-350, іх різання - ротаційний мікротом серії НМ - 340Е. Гістологічні препарати фарбували гематоксиліном і еозином в автоматі Robot-Stainer HMS-740.

Bci апарати виробництва фірми Carl Zeiss MICROM International GmbH. Використовували мікроскоп Axioskop 40 з фотокамерою Axio Cam MRc5 (Karl Zeiss).

\section{Результати}

У 28 (56\%) пацієнтів виявлено два захворювання анального каналу і прямої кишки, у 17 (34\%) - три, у 4 (8\%) чотири, у 1 (2\%) - п'ять (див. таблищю).

У разі використання високочастотного електрохірургічного апарата «KLS Martin» тривалість операції становила в середньому $(15 \pm 5)$ хв, у контрольній групі - (30 $\pm 5)$ хв, об'єм крововтрати - відповідно (20 \pm 10$)$ та (40 \pm 10) мл. Больовий синдром у післяопераційному періоді був більш виражений у пацієнтів контрольної групи, вони потребували для знеболювання (4 \pm 1$)$ мл наркотичних засобів. У досліджуваній групі пацієнти потребували для знеболювання всього (2 \pm 1$)$ мл наркотичних засобів. Тривалість лікування у стаціонарі пацієнтів досліджуваної групи становила (4 \pm 1$)$ день, контрольної - (7 \pm 1$)$ день.

У післяопераційному періоді у пацієнтів досліджуваної групи не виявлено ознак недостатності анального сфінктера і формування рубцевої стриктури анального каналу. У контрольній групі у 2 (4\%) пацієнтів сформувалась рубцева стриктура анального каналу, яку вилікували у 1 пацієнта консервативними заходами, у 1 - оперативними.

За даними морфологічного дослідження встановлено, що у разі використання високочастотного електрохірургічного апарата «KLS Martin» відбувалися розсічення тканин і їх коагуляція з контролем гемостазу та утворенням тонкого шару коагуляційного некрозу, середня глибина якого становила $(0,192 \pm 0,12)$ мм (рис. 1$)$.

Використання хірургічного металевого скальпеля супроводжувалось механічною травматизацією і крововиливами в краях операційної рани, що в подальшому уповільнювало їі загоєння (рис. 2). 


\begin{tabular}{|c|c|c|c|}
\hline \multirow{2}{*}{ Варіант поєднаної патології } & \multirow{2}{*}{ Характер операції } & \multicolumn{2}{|c|}{ Кількість пацієнтів } \\
\hline & & абс. & $\%$ \\
\hline Хронічна анальна тріщина, анальний поліп & Висічення тріщини, поліпектомія & 8 & 16 \\
\hline $\begin{array}{l}\text { Хронічна анальна тріщина, анальний поліп, комбінований } \\
\text { геморой }\end{array}$ & $\begin{array}{l}\text { Висічення тріщини, поліпектомія, } \\
\text { гемороїдектомія }\end{array}$ & 7 & 14 \\
\hline $\begin{array}{l}\text { Хронічна анальна тріщина, анальний поліп, гіпертрофовані } \\
\text { періанальні шкірні мітки }\end{array}$ & $\begin{array}{l}\text { Висічення тріщини, поліпектомія, } \\
\text { електроексцизія міток }\end{array}$ & 5 & 10 \\
\hline Комбінований геморой, хронічний парапроктит & Гемороїдектомія, висічення фістули & 4 & 8 \\
\hline Зовнішній геморой, хронічна анальна тріщина & Гемороїдектомія, висічення тріщини & 4 & 8 \\
\hline Комбінований геморой, хронічна анальна тріщина & Гемороїдектомія, висічення тріщини & 4 & 8 \\
\hline Хронічний парапроктит, анальний поліп & Висічення фістули, поліпектомія & 2 & 4 \\
\hline Анальний поліп, гіпертрофовані періанальні шкірні мітки & Поліпектомія, електроексцизія міток & 2 & 4 \\
\hline $\begin{array}{l}\text { Зовнішній геморой, гіпертрофовані анальні сосочки, } \\
\text { гіпертрофовані періанальні шкірні мітки }\end{array}$ & $\begin{array}{l}\text { Гемороїдектомія, папілектомія, } \\
\text { електроексцизія міток }\end{array}$ & 2 & 4 \\
\hline Анальний поліп, комбінований геморой & Поліпектомія, гемороїдектомія & 1 & 2 \\
\hline Зовнішній геморой, хронічний парапроктит & Гемороїдектомія, висічення фістули & 1 & 2 \\
\hline $\begin{array}{l}\text { Хронічний парапроктит, хронічна анальна тріщина, } \\
\text { анальний поліп }\end{array}$ & $\begin{array}{l}\text { Висічення фістули, висічення тріщини, } \\
\text { поліпектомія }\end{array}$ & 1 & 2 \\
\hline $\begin{array}{l}\text { Хронічна передня анальна тріщина, хронічна задня } \\
\text { анальна тріщина, анальний поліп, хронічний парапроктит }\end{array}$ & $\begin{array}{l}\text { Висічення тріщин, поліпектомія, } \\
\text { висічення нориці }\end{array}$ & 1 & 2 \\
\hline $\begin{array}{l}\text { Хронічна анальна тріщина, хронічний внутрішній геморой } \\
3 \text { ступеня }\end{array}$ & Висічення тріщини, гемороїдектомія & 1 & 2 \\
\hline $\begin{array}{l}\text { Комбінований геморой, хронічний парапроктит, } \\
\text { гіпертрофована періанальна шкірна мітка }\end{array}$ & $\begin{array}{l}\text { Гемороїдектомія, висічення фістули, } \\
\text { електроексцизія мітки }\end{array}$ & 1 & 2 \\
\hline $\begin{array}{l}\text { Хронічна анальна тріщина, комбінований геморой, } \\
\text { гіпертрофована періанальна шкірна мітка }\end{array}$ & $\begin{array}{l}\text { Висічення тріщини, гемороїдектомія, } \\
\text { електроексцизія мітки }\end{array}$ & 1 & 2 \\
\hline $\begin{array}{l}\text { Хронічна анальна тріщина, анальний поліп, періанальні } \\
\text { кондиломи }\end{array}$ & $\begin{array}{l}\text { Висічення тріщини, поліпектомія, } \\
\text { електроексцизія кондилом }\end{array}$ & 1 & 2 \\
\hline $\begin{array}{l}\text { Хронічна передня анальна тріщина, хронічна задня } \\
\text { анальна тріщина }\end{array}$ & $\begin{array}{l}\text { Висічення передньої і задньої анальних } \\
\text { тріщин }\end{array}$ & 1 & 2 \\
\hline $\begin{array}{l}\text { Хронічна передня анальна тріщина, хронічна задня } \\
\text { анальна тріщина, анальний поліп, хронічний парапроктит, } \\
\text { гіпертрофована періанальна шкірна мітка }\end{array}$ & $\begin{array}{l}\text { Висічення передньої і задньої анальних } \\
\text { тріщин, поліпектомія, висічення фістули, } \\
\text { електроексцизія мітки }\end{array}$ & 1 & 2 \\
\hline $\begin{array}{l}\text { Хронічна анальна тріщина, комбінований геморой, } \\
\text { анальний поліп, гіпертрофована періанальна шкірна мітка }\end{array}$ & $\begin{array}{l}\text { Висічення тріщини, гемороїдектомія, } \\
\text { поліпектомія, електроексцизія мітки }\end{array}$ & 1 & 2 \\
\hline $\begin{array}{l}\text { Хронічна анальна тріщина, гіпертрофовані анальні } \\
\text { сосочки, ліпома періанальної ділянки }\end{array}$ & $\begin{array}{l}\text { Висічення тріщини, папілектомія, } \\
\text { видалення ліпоми }\end{array}$ & 1 & 2 \\
\hline
\end{tabular}

\section{Обговорення}

Застосування високочастотного електрохірургічного апарата "KLS Martin” для лікування хворих з поєднаною патологією анального каналу і прямої кишки приводило

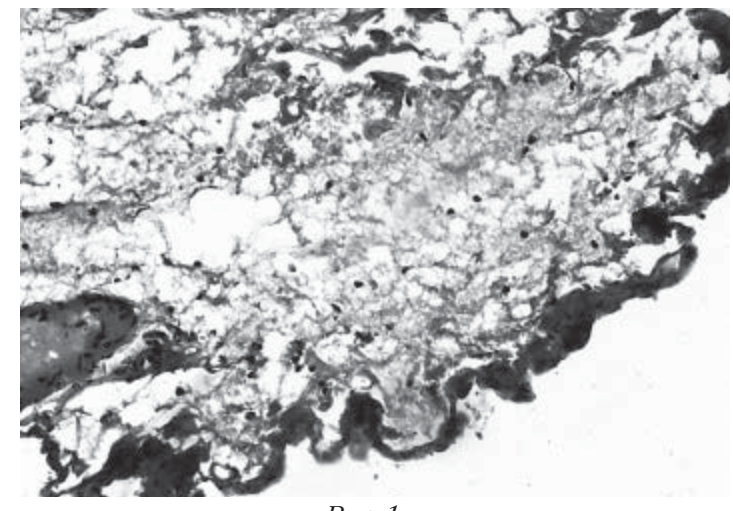

Puc. 1.

Мікрофото. Збереження тканинної структури з утворенням тонкого шару коагуляційного некрозу після використання високочастотного електрохірургічного апарата «KLS Martin». Забарвлення гематоксиліном і еозином. 3б. ×100. до зменшення тривалості оперативних втручань, яка становила в середньому $(15 \pm 5)$ хв, зменшення втричі об'єму крововтрати під час операції, яка становила в середньому $(20 \pm 10)$ мл, утворення тонкого шару коагуляцій-

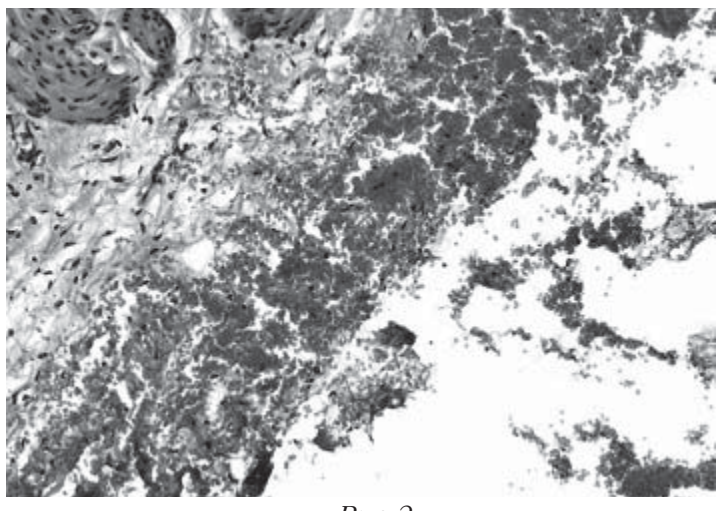

Puc.2.

Мікрофото. Край рани після використання металевого скальпеля - поширені крововиливи.

Забарвлення гематоксиліном і еозином. $3 б . \times 100$. 
ного некрозу в тканинах, середня глибина якого становила $(0,192 \pm 0,12)$ мм, завдяки чому у пацієнтів вираженість больового синдрому була вдвічі меншою і вони потребували вдвічі менше наркотичних засобів для знеболювання порівняно з контрольною групою.

Застосування хірургічного металевого скальпеля супроводжувалось утворенням поширених крововиливів у тканинах, що обумовлювало їх більшу травматизацію і відповідно більш виражений больовий синдром у пацієнтів контрольної групи.

Вплив на тканину у разі використання високочастотного електрохірургічного апарата «KLS Martin» був мінімальним, що сприяло формуванню косметичного післяопераційного рубця, запобігало виникненню рубцевих стриктур анального каналу, а також зменшувало строки загоєння ран, обумовлюючи швидшу реабілітацію пацієнтів досліджуваної групи.

\section{Висновки}

1. Застосування високочастотного електрохірургічного апарата «KLS Martin» скорочує тривалість операції, зменшує втричі об'єм інтраопераційної крововтрати та вдвічі інтенсивність больового синдрому в післяопераційному періоді, а також скорочує строки лікування пацієнтів, що обумовлює їх швидку медико-соціальну реабілітацію.

2. Після використання зазначеної електрохірургічної методики порівняно з використанням хірургічного металевого скальпеля швидше загоюється післяопераційна рана з формуванням ніжного еластичного рубця без рубцевих стриктур та недостатності анального сфінктера.

\section{References}

1. Borota AV, Hul'mamedov FI, Hulmamedov VA, Polunin GE, Plakhotnikov IA, Shalamov VI. Khirurhicheskoe lechenie sochetannoi neopukholevoi patologii anal'nogo canala i priamoi kishki. Koloproctologia. 2016;4(58):22-5. [In Russian].

2. Rajymbekov OR, Zholbolduev ZhM, Ajdarov UA. Sovremennye vzgljady na diagnostiku i lechenie pararektal'nogo svishha v sochetanii s hronicheskim gemorroem. In: materialy vserossijskoj nauchno-prakticheskoj konferentsii s mezhdunarodnym uchastiem. 2017. 10. 26-28; Voronezh. Koloproctologia. 2017;3(61):37-8. [In Russian].

3. Dmitrichenko VV, Caregorodcev AE, Ushkac AK. Primenenie apparata "Ligasure" pri operativnom lechenii hronicheskogo gemorroja. In: materialy III vserossijskogo siezda koloproktologov. 2011.10.12-14; Belgorod. Koloproctologia. 2011;3(37):27. [In Russian].

4. Milito G, Lisi G, Sileri P, Aronadio E, Grande M. Liga Sure hemorrhoidectomy: how we do it. In: abstracts of the 11th Scientific and Annual Meeting of the European Society of Coloproctology. 2016.09.28-30; Milan. Colorectal Disease. 2016;18(1):119.

5. Timerbulatov VM, Fajazov RR, Mehdiev DI. Nedostatki i oslozhnenija pri gemorroidjektomii metodom jelektroligirovanija. In: materialy III vserossijskogo siezda koloproktologov. 2011.10.12-14; Belgorod. Koloproctologia. 2011;3(37):51. [In Russian].

6. Milito G, Lisi G, Sileri P, Aronadio E, Grande M. Liga Sure versus conventional haemorrhoidectomy: a retrospective monocentric study. In: abstracts of the 11th Scientific and Annual Meeting of the European Society of Coloproctology. 2016.09.28-30; Milan. Colorectal Disease. 2016;18(1):119-20.

7. Danilov MA, Atroshhenko AO, Hat'kov IE. Preimushestva ispol'zovanija HARMONIC FOCUS pri vypolnenii otkrytoj gemorroidjektomii. In: materialy vserossijskogo siezda koloproktologov s mezhdunarodnym uchastiem. 2016. 8. 25-27; Astrakhan'. Koloproctologia. 2016;2(56) (prilozhenie):24. [In Russian].

8. Il'kanich AJa, Abubakirov AS, Nuretdinova LA. Gemorroidjektomija s sochetannym primeneniem apparata Ligasure i skal'pelja Ultracision. In: materialy III vserossijskogo siezda koloproktologov. 2011.10.12-14; Belgorod. Koloproctologia. 2011;3(37):30. [In Russian].

9. Kuz'minov AM, Borisov IF. Gemorroidjektomija s primeneniem vysokih jenergij Koloproctologia. 2009;3(29):46-51. [In Russian].

10. Solov'jov OL, Solov'jov AO, Solov'jova GA. OUT-PATIENT tehnologija gemorroidjektomii. In: materialy vserossijskogo siezda koloproktologov s mezhdunarodnym uchastiem. 2016. 8. 25-27; Astrakhan'. Koloproctologia. 2016;(2) (prilozhenie):42. [In Russian]. 